\title{
TELEVISUAL ARCHIVE: IMAGINARY, MEMORY, AND RE-VISITED SOCIAL BOND
}

\author{
MARIO BRESSAN* \\ HELOISA MORAES**
}

* marioabelbj@gmail.com

UNISUL - Universidade do Sul de Santa Catarina - Brazil

**heloisapreis@hotmail.com

UNISUL - Universidade do Sul de Santa Catarina - Brazil

\begin{abstract}
This study aims to expose some thoughts about the reformulation of the social bond constituted with the television, through remembrances evoked among television viewers involving a tele-affective memory and new formats inside audiovisual consumption. In addition to this, it analyses the comments of people that watched a remake of the Brazilian program Cassino do Chacrinha (Chacrinha's Casino), which aired in 2017 on Rede Globo de Televisão (TV Globo) and Canal Viva (Viva), commemorating the centenary of Abelardo Barbosa, a very important Brazilian TV host who acted between the '70s and '80s. Our methodology follows the Content Analysis mobilised by Laurence Bardin (2011) in relation to texts posted on Twitter containing the expression "Cassino do Chacrinha" in August 3, 2017 (aired on Viva) and September 6, 2017 (aired on TV Globo). We want to discuss the relationship between imaginary, memory, and social bond starting from a televisual archive, where we present tele-affective marks of memory through substantial and shared images that appear in these analysed comments.
\end{abstract}

Keywords: Memory, Televisual archive, Television, Social bond, Chacrinha. 


\section{Introduction}

We have promoted research that seeks to discuss the social bond formations from the technologies of imaginary, devices of image formation that make sense collectively. The television is still one of these devices that bring to the day-to-day scenario certain images that symbolically possess a power of collective adhesion. Even though using aesthetic updates, here we are specially talking about scenes of reminiscence mobilised by the televisual archive, which creates a connection of belonging - and, for this reason, is affective. Therefore, we think that social bond theorised by Wolton (1996) suffers some alterations when related to the new spaces of audiovisual consumption in the face of the hyper-television (Scolari, 2014) and post-television (Cádima, 2014).

This study wants to expose thoughts about the reformulation of the social bond with the television through the remembrances evoked among television viewers, with the actuation of a tele-affective memory, and new formats of audiovisual consumption. As objects, we chose the remake of the Brazilian program Cassino do Chacrinha (Chacrinha's Casino), aired in 2017 on TV Globo's e Viva channel, commemorating the centenary of Abelardo Barbosa, an important Brazilian TV host between the '70s and ' 80 s. It is valuable to say that Barbosa, the aforementioned Chacrinha, is an icon in the Brazilian communication network, and also owner of a personal style and a very singular TV programme. Known as Velho Guerreiro (Old Warrior), Chacrinha started his career on the radio, but made history on television, debuting on TV Globo in 1967, where he hosted some successful variety shows. In 1988, he passed away at 70 years old. The Chacrinha's Casino was one of those variety shows, famous for the host's eccentricity and extravagance from the outfit to the way the programme was conducted, as well his catchphrases known even now (Memória Globo, 2019).
For those discussions, we raise the research questions: 1) from the actuation of a tele-affective memory, how is the social bond, formed by generalist television, restructured by the public that (re)watches the same format and elements of a mass programme aired in the '70s-'80s, both on FTA (freeto-air TV) and pay TV? 2) What is the televisual archive's role in restructuring a TV programme after thirty years? 3) What kind of imaginary we can identify in the affective relation of the television memory?

We have the support of claims that images acquire their strength through common existence, as stated by Maffesoli (2007, p. 12), when "the ethic, a social connection's base, relies structurally on the aesthetics: it is this capacity of experimenting emotions, sharing and transforming them in the cement of a society". This ethic of aesthetics, which puts the social imaginary in motion, projects images allegorically expressive that make sense in a collective way, either by imagination (becoming images) or memory - images from the past full of meaning and affectivity, always acquiring potency through emotion. Here, in this paper, we are actually introducing this notion about an imaginary that is strengthened by connection, a device originated in the televisual archive. Crafted by Bressan Júnior (2019), it is nominated tele-affective memory.

The television intensifies an affective memory, because it pertains to a referential group and to a social context. Even being an individual activity, the memory is formed with the participation of this individual in certain groups, as stated by Halbwachs (2003). According to him, this happens because people remember situations that are, and were, constituted inside referential groups. In the face of a televisual archive, the television viewer remembers some situations from the past and, consequently, some feelings come back through images that are re-exhibited. There is a collective memory, which is restored by the TV archives. 
On the individual, or collective, anthropological journey (Durand, 2002), we absorb, carry and redefine archived emotions, sensations, and experiences by way of images. In this trajectory, "the memory is a precious instrument where the imaginary displays itself and (re)builds symbolical and everyday actions" (Moraes, Bressan, Jorge, 2018, p. 162). Thus, our intent is to analyse the marks of affection and meaning in observing images that update and generate a symbolical ambiance, a sort of collective aura. Those so-called images are perceptible in the narratives created by the comments presented on Twitter.

We expect those discussions, contributing to the reflections concerning meanings and social ambiances, to be managed by the technology, ambiances that mark both ethic and aesthetics in contemporaneity, specially mediated by the television, and anchored with images that are capable of mobilising social imaginary through the tele-affective memory.

\section{From the televisual archive to tele-affective memory}

Since its first steps, the television shows us how important it is to study it as a social environment of symbolical and affective production. Besides, it acts like a "floating" archive with content, keeping, recovering, and exposing elements for later recollection.

In this history, Umberto Eco (1984) offers two categories to distinguish the TV's function - Paleotelevision and Neotelevision - where the very first consists of a more informative phase with "[...] almost nothing to contemplate", and the second one differently claims the entertainment oversteps of the television experience (Eco, 1984, p. 203). Being in front of the TV characterises what Wolton (1996) defines as Social Bond. Wolton states that mass-TV presents two functionalities partially distinct: 1) it supports the social bond in society, which is standardised; 2) it concedes, simultaneously, this bond in a context that is emerged to be even more conflicting. It is an important transversality if we analyse the different cultural and symbolical manifestations of the television audience. A single programme can unite individuals, regardless of social, cultural, and religious class where they are immersed.

In the words of Cádima (2006, p. 53), the television produces and recycles collective identities, as well as creating shared symbolic mechanisms, "a common symbolical life." This can be perceived, as say by Cádima, as a content intermediation strategy. Those paths direct us to privative and communitarian experiences.

The television's strength is in reconnecting the levels of individual and collective experience; it is the only activity that can have an equal connection between wealthy and poor people, young and old, country and urban communities, cultured and uncultured. Everyone watches TV and talks about it. Nowadays, what other example of an activity is so transversal? If the television did not exist, many people would dream of creating an instrument capable of reuniting all the publics together. This is what the theoretical unity of television is (Wolton, 1996, p. 16).

It is on the television, as Wolton (1996) states, that the social bond is created, exactly in this reconnection function, which brings us to a point of unity. He says that the television works as an instrument of communication between individuals just by the fact of regularising its conversations about what we see on the TV, instead of what is watched. For that reason, the TV is an object that enables the conversation about exhibited content, both inside and outside the home. "So, it is an indispensable social bond on a society where individuals often stay isolated and, sometimes, solitary" (Wolton, 1996, p. 16).

In other institutions - church, work, school, family, in the "institutionalized practices" - the formation of the social bond was already being established. Accordingly, as described by Wolton (1996), there always was the formation of a trace 
linking individuals. However, when TV arrived to the world, this started to be recognised in the field of audience reception. For him, the television became the "mirror" of society, where the spectator could see itself.

Notwithstanding, according to Wolton (1996), the social bond on the television only happens in the free-to-air modality, because it offers a common programming in a society considered, for the author, individualistic. Nonetheless, we also consider it possible to observe this social bond on pay TV and on demand programming, because there is an objective to unify a public that watches it, providing individual and collective experiences.

This bond starts to be identified, consequently leaving behind anonymity, when television viewers participate on social media websites. This can be one of the main changes in the history of how we can understand the television as a cultural-social phenomenon. Even inserted on other screens and platforms, the audiovisual consumption goes on, but we consider the permanence of a social bond, coming out of an invisible web. The conversations in social media, about television content mark out their existence and transfer the readjustment of a new unity to transmediation, another format of social connection and union, now ubiquitous, these being features of the current phase of television.

As Cádima (2011, p. 12) explains, the participation on the network attends to the necessity of a " $20^{\text {th }}$ century's social bond," and reconfigures a substitution related to our tendency to be conditioned to the old box television, with no more limits to the information. Systems and technologies provide new experiences reuniting content and social participation. Along with the "classic media" to the "new media" change, Cádima (2014) also says that there was a change of communicational paradigm, where a new post-television device appeared. This allowed things like interactivity, ubiquity, immersion, hybridism, matriciality, and remediation.
The TV archive function keeps facts and images registered, and there are several registers: news, fiction, narratives, varieties, etc. In other words, situations where the television "speaks" informatively (Paleotelevision) and about itself (Neotelevision), evoking memories, in a specific moment, when airing them (the registers) at a later time.

The act of remembering is to bring back an epoch that was stored, hidden, or little visited in our minds. From this perspective, the television rests in a device that produces uninterrupted memories to the television viewers. When it repeats a TV programme, the television exposes elements that are noted and thus a remembrance will be jogged. The televisual archive carries in itself a quality: remembrance of the past.

The memory only happens because people search the reminiscences in terms of what is preserved inside them. Based on that, the televisual archive has meaning when, along with obtaining the function of keeping registers (constituted by an audiovisual repository), it establishes a signification that outdoes the technical apparatus. That is to say, the TV archive can only be constituted as a sociocultural device if there is a memory lived and perceived by the television viewer. The archive is a machine; the memory is human.

In this memory's reminder relation, affections are present when the televisual archive brings meaning to the public. People are socially constituted in an affective relationship. Inside this context, Bressan Júnior (2019) presents the tele-affective memory, evidenced by the reformulation of a social bond, and strengthened by referential groups that help to constitute memories and affections.

The tele-affective memory recovers a remembrance from a lived experience in a specific epoch or year, or related to specific data, where people had been through events facing a televisual archive that was (re)exhibited and remembered. A scene, a notice, or music, for example, can trigger pleasant 
and sentimental sensations about something that had been lived. This happens because an affective relation is intensified by the television.

This tele-affective memory is responsible for recovering, and reformulating some reconstituted reminiscences from images exhibited on the television, and by affections around the vibrations provoked by it. Besides the socializing work (Ferrés, 1998), and the Social Bond (Wolton, 1996), the television can be one of those "places" (Halbwachs, 2003) that we (re)visit and are noted by our memories (Bressan Júnior, 2019, p. 96).

It is called tele-affective because is in an emotional relation that only television (audiovisual consume) allows to happen, though. This archive on the television is an object that establishes a socio-affective mediation with the public. The tele-affective memory revives a remembrance from a lived experience in a particular period, date, or year, when people felt, or remembered something when in front of the TV. This is different to an affective memory (Bressan Júnior, 2019), because a tele-affective memory brings pulses generated by the visualisation of television images, those induced by emotional effects during the act of rewatching. This tele-affectivity of the memory, in this case, is a result of a reformulated social bond through remembrances (Bressan Júnior, 2019).

With the televisual archive's role of bringing back a past, the social bond proposed by Wolton (1996) is rebuilt with the affective memories of the TV audience, because of the affections disposed in this rescue. This invisible web starts to be redrawn using old and recent experiences. There is an emotive pulse in the remembrance that adds a delineated "double thread," which is a consequence of a déjà vu interference.

Déjà vu on the television provides constant bonds. Whoever watched a programming long ago, consequently is in a social bond. So, when this particular individual sees the scene again, other bonds are constituted, aside from the one formed during that past moment, everything starting from a rescued memory.

When mobilised, the tele-affective memory foments feelings that are negotiated through presented images on the individual imaginary, but gains a collective mobilisation that creates the social and identification bond around its symbols. In other words, this image-formed journey can be remembered and updated with the imaginary's own capacity. We are going to discuss its faculty of remembrance in the next section.

\section{Imaginary and remembrance images}

Discussions relating Memory and Imaginary take into consideration the symbolic character of the social life, because it is by means of this symbolic bond that the common understanding about the distribution of the sensible occurs. Maffesoli (2007) bases his analysis concerning the postmodern imaginary of daily life's unity in sensible forms. It is into this circuit that we set our object of analysis or, more precisely, the excerpt we will analyse allows us to discuss, through narrative-testimonies, feelings and living marks symbolically mobilised by the televisual archive.

The memory allows us to revisit a lived time or yet to create a symbolical environment of yearning for bygone days and belonging through images. Relying on this affirmation we find people that did not live in such period, but feel themselves attracted, sharing the moments and their cultural ambience, symbolically. Durand (2002, p. 403) states that "the memory - as an image - is this vicariant magic which an existential fragment may resume and symbolize the wholeness of the regained time". Therefore, based on Durand's saying, we can infer that memory has a fundamental effect on the imaginary, as a euphemism, the "fantastic function of the memory" (Durand, 2002, p. 402). 
A remembrance's mechanism makes the past accessible using the imaginary. The memory is a faculty of the imaginary, just as imagination, often imbricates itself to that. We understand this - the imaginary - in Durand (2002, p. 18) as "the group of images and image relations that constitute the thought capital of the Homo sapiens," a great denominator in human creations.

Maffesoli (2007) defends the idea that postmodern fantasies are anchored in customs: a physical figure may present feelings and passions that come from far away, past times. Figures, images, "are symbolical as far as they unite, ensure the coherence, and make an invisible force visible" (Maffesoli, 2007, p. 115), where, consequently, they make a group, a community. There is a "retentive conscience" that guarantees the presence of the past into the present. In this sense, those figures brought by Maffesoli conduct us beyond ourselves. In brief, the "noted" became sedimented and continues to live, being updated in daily life. Every phenomenological perspective rests on comprehending this "have-been" that lives on in a vestigial form, however "functional" (Maffesoli, 2017, p. 116).

This is a dynamic foundation, whose processes of reminiscences make us participate in a collectivity, a community (Maffesoli, 2007). The practical living of individual experience is embedded in the collective experience. There are "memorials", contemplated images, which allow not only the remembrance's process, but also the identification and belonging's processes in the context of the social bond. The imaginary is formed through the creator's potential, since we forge image to perform our daily life actions while symbolical beings (Moraes, 2019). So, "the imaginary depicts itself as a semantic reservoir that strengths the daily life" (Moraes, Bressan, Jorge, 2018, p. 166).

For this reason, as presented by Durand, we believe in the images' semantism, the fact of it not being only signs, but that "they materially contain its meaning somehow (Durand, 2002, p. 59). In addition, because of this semantism in the television viewers' narrative from the televisual archive, we seek those marks of tele-affective memory, the creator of connections and mobiliser of imaginaries.

\section{Methodology}

This research uses the internet as a field of analysis, namely the terms posted on Twitter talking about Cassino do Chacrinha, aired by Viva in August 26, 2017, and TV Globo in September 6, 2017.

Fragoso, Recuero, and Amaral (2013) affirm that the internet can be an object (what is studied), locus (space where the investigation is done), and instrument of research (mechanism for data collection). That way, we have it as a field to find elements and information in order to bring about the analysis. The methodology has its base in actions and concepts of transmediation, which have been growing large in Brazil.

Brazilians' participation in this investigation network has been increasing. In 2017, Lopes and Greco (2018) emphasized that the Brazilian soap opera A Força do Querer (Edge of Desire TV Globo) obtained 829 million impressions on Twitter, in six million tweets. "Data from Kantar Ibope Media indicate that was the TV fiction with the biggest repercussion on Twitter in 2017" (Lopes, Greco, 2018, p. 123).

In light of these data, we justify the use of Twitter for the investigation, seeing that, as described by Lopes and Greco (2016), it is considerable, and distinguishable, and acknowledging the importance of this tool as a sharing space that includes content and "conversation" about fiction. Besides, social media allow a marginal interlocution: "interactions with the information (or content's searching) have been established by the energy awaken on the action of symbols and affections" (Moraes, 2019, p. 98). Thus, it is possible, with social media, to manifest a symbolic adhesion and to establish a social bond. 
Likewise, this choice is based on what Fechine (2014) calls "extended sofa" inasmuch as they are classifications of interpersonal conversations that happen offline and migrate to the online space. Those are topics presented in the social bond, in people's daily lives, regulating discussions as well.

As methodology, Content Analysis from Laurence Bardin (2011) is applied, because we are in the face of discursive manifestations concerning the study's object. For the author, the content analysis rests on displaying quantitative or qualitative indicators, a particularity that allows us to know the conditions of production and reception of the messages. The first step is to exhibit the numbers of posts quantitatively. After that and a floating reading of the comments, we go for the development of the categories of analysis.

Bardin (2011) sustains the criteria to categorise and group data can be semantic (thematic categories), syntactic (verbs, adjectives), lexical (meaning of words, synonyms) and expressive (categories that express different conflicts of language). The importance in classifying those elements depends, as states Bardin, on the proximity those elements may have. For this reason, the classification enables us to see common parts among them.

We chose the semantic categorisation in order to establish thematic categories. From this, the objective is to study them in conformity with the elements that will appear in the television viewers' discourse, when commenting about the centenary of Abelardo Barbosa, the Chacrinha.

We collected data with the help of a tool named "Grid Monitoramento", which allows the insertion of searched terms and obtainment of posts' first classification. This software is used by the UNISUL (aka Universidade do Sul de Santa
Catarina - "University of the South of Santa Catarina"), where the researchers of this study work, and it acts as a monitor on social media sites and provides a searching system to find keywords on Twitter.

The data were collected on both exhibition days: firstly on Viva, afterwards on TV Globo. Following the semantic criteria of the comments, we divided the contents that presented some sort of remembrance in front of the televisual archive. In the next chapter, showing the analysis, it is possible to see the initial procedures of investigation.

\section{(Re)union of the TV audience: memory and social bond}

In total, 671 tweets were collected from television viewers that watched the tribute programme for Cassino do Chacrinha on Viva and 1,595 from those who saw it on TV Globo a few days after.

In the comments of August 6, 2017, during the exhibition of Programa do Chacrinha, o eterno guerreiro (Chacrinha, the eternal warrior) on Viva, eight of them brought some remembrances into their phrases; on TV Globo, thirty comments showed reminding contents. 1

We could perceive the televisual archive, in this analysis, is the same for both channels. We did not observe differences in the presented comments. The programme was aired first on Viva, a pay TV channel, and one week after for all the country via free-to-air transmission.

1 Tweets were described in the same way they were published by the television viewer. We put the entire posted content and we separated it by communication vehicle: a) first part of the table shows the comments on Viva; b) in the following part are the ones posted by the TV Globo viewers. There will be a translation for each tweet displayed. 


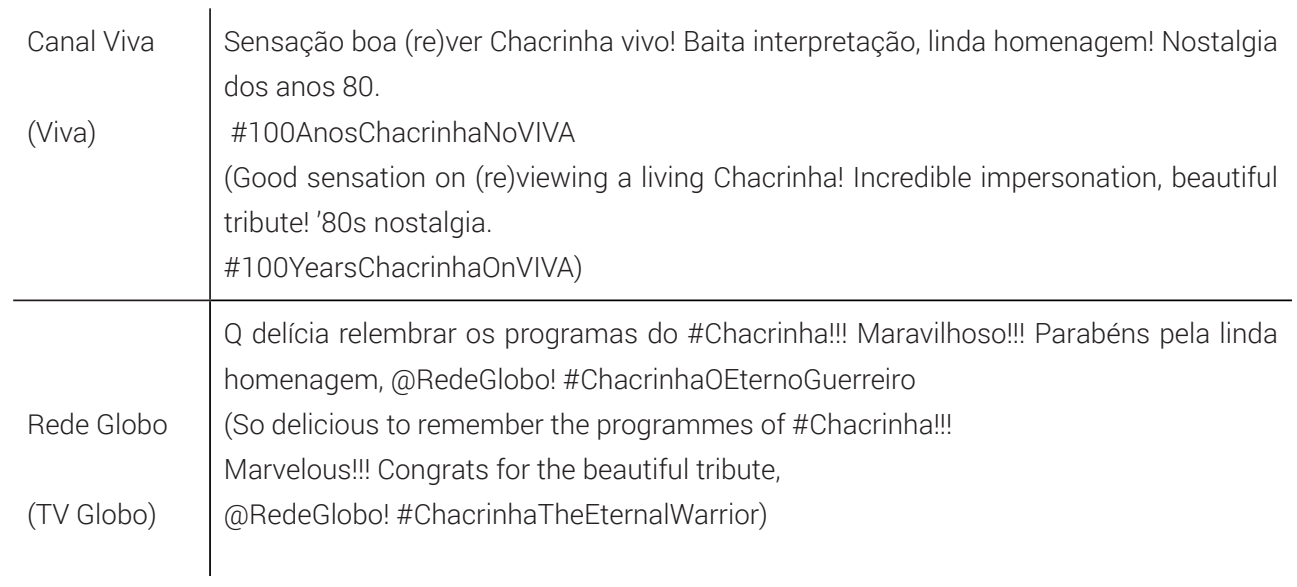

For example, the above comments delineate one and same meaning for both exhibitions. The TV empowers an affection, a feeling of happiness and pleasure in exhibiting yet again Chacrinha's Casino. Expressions like sensação boa (good sensation), linda homenagem (beautiful tribute), nostalgia (nostalgia), Q delícia (so delicious), maravilhoso (marvelous) express similar manifestations, and confirm the televisual archive's function in revisiting a social bond constituted years ago. In front of the pay or free-to-air TV, the bond created, and later remembered, is the very same when it is being exhibited.

On the expressions posted on the web, there is a group of feelings strengthened by reliving the programme, even this being a reconstitution based on the orginal content. For the public, the remake accomplished the mission of bringing back again Abelardo Barbosa and his irreverence.

In the analysed tweets, we noticed that the television viewers manifested nostalgia, remembered some parts of their lives, and qualified the past as a good, unique, and different time in comparison with the present.
About the ones who externalised nostalgic demonstrations, all of them describe a positive feeling that also does a good thing to the mind with the images exhibited.

It is possible to see in the posts above a reunion between the TV audience with the past. Everyone states the pleasure of turning back time, of missing something, and being in front of something that provides such moments. This is the induced social bond's job when we revisit the televisual archive. It recovers images from a long time ago and presents new pulses through reminiscence. We believe there is a strength inside the subject willing to redo this bond. When it exhibited the Chacrinha's Casino for the first time, television participated both in the collectivity and in the socialization. By revisiting the places with this remake production, the bond re-appears with another thread, now doubled: the first one refers to what was lived in the past; the second, now, refers to interferences concerning the first bond and "patches" of fond memories. Such memories can be both happy and sad, and are susceptible to verification in the semantic expressions that constitute the comments. 
One of the viewers claims to cry when re-watching the program, another says they miss their aunt. In the last tweet, there is a moment of happiness intensified by this "good memory," coming to a point where the viewer claims for God, because of its testimony over the images.

There is a tele-affective memory that validates the televisual archive, reconstructing a past invisible web, and restructures itself in the present with affections reappearing when the past is remembered.

What happens is an affectivity in account of charts and groups of reference justified by Halbwachs (2003). It is in the collectivity that we identify ourselves as social beings and emotionally belonging to the world. Thereupon, the collective memory (Halbwachs, 2003) is important for our comprehension of the socio-affective functions with each other. Through the redisplayed archive, the TV foments a link between the phases lived by us. The comments below bring to light this linking with two important phases in the television viewers lives: childhood and adolescence.

It is only possible to establish this affective relation with childhood and adolescence when we are in front of a TV, because it is through it that a tele-affective memory is constituted. As little kids, we watched specific programmes and, regardless of being alone or together with family or friends, the television was there. There is a confirmation in these comments: the Chacrinha's Casino became united with the young television viewer, who recreates a social bond and evokes a tele-affective beyond affective memory - all of this when he/she is an adult facing the televisual archive.

The tele-affective memory potentiates this adult-child relation, since there is a desire for reconstruction, reformulation of memories and the social bond formed long ago. Even in an unconscious form, the television viewer asks for that. The egocentric relation occurs because of affectivities and desires presented to the public that watched the programme Chacrinha, o eterno guerreiro (Chacrinha, the eternal warrior).

In both the free-to-air and pay TV television viewers' comments, the effects of meaning are the same: they do not differ in terms of the social bond's formation, which is revisited years later. Thus, no matter how it is exhibited (platform or device); the tele-affective memory will be present.

Things like that bring us to think about today's audiovisual consumption, with on demand and ubiquitous programming. We conclude that social bond, reformulated by the televisual archive, can happen in any environment where it is exhibited, because of the affective manifestations provided with the relation between television and public.

In this process, there is a reconquered tele-affective memory, which reformulates a new experience, surrounded by feelings. "As explained by Halbwachs (2003), sometimes is necessary to make use of exterior declaration as sort of a seed of reminding, in order to prompt the memories" (Bressan Júnior, 2019, p. 95). TV executes this role when configuring an external device that helps bring us back to a past movement.

The exhibition of an audiovisual archive raises important questions about the socio-affective composition of the memory and its affections. Its strength becomes evident as a time-transposition mechanism, as we see in the next tweets.

Wolton (1996, p. 16) observes that television presents the function of establishing the social bond, whose strength is "on reuniting the levels of individual and collective experience". The comments above attest to those social and individual relations of the television viewers. Even not appearing in the posts of the programme during the transmission on Viva, in the course of the exhibition of Eterno Guerreiro on TV Globo, we observed three evidences of where the televisual archive transported someone to a period when the experiences from 
television viewers were pulsating and remembered with affections. In the three phrases, the word tempo (time) shows up together with other expressions that mark how good Chacrinha was and how much they miss those times.

The collective and individual experience happens because of the programming, and Wolton (1996) states that is an essential activity on television and we need to understand it as three phenomena. Firstly, the calendar and structuration functions, once the TV is a sort of pure clock of daily life; secondly, we must comprehend, clearly, what information is and what programmes are; thirdly, the respect among the several programming genres, understanding the offer and demand of different types of programming.

It is necessary to specify that the social bond explained by Wolton (1996) materialises in the televisual archive and social media websites, because it proves that there is an invisible web uniting people when they are watching and commenting about the subject. On the internet, the bond becomes visible, since we can quantify and identify the individuals who watch, like, and comment on there.

The TV possesses a back and forth particularity, where narratives have a "ping-pong" effect; it is able to show the past to be compared with other pasts and the present time. Television is like a place with archives serving to trigger memories. With technological advancement, the access to mobile devices, and the digital archive, that is increasingly more apparent.

\section{Final Considerations}

In this research, we concluded that the televisual archive allows the social bond to bring back the "be with". Nostalgia manifestations, the acts of "reviewing" itself as a child or teen, and remembering a "good time", as stated by television viewers, were decisive enough to conclude that the subject always remembers something intermediated by other people and because of its insertion in a collective, and social, context. The tele-affective memory contributes to the formation of a social bond, attesting to the importance of the televisual archive in reconstructing the TV programme, and acknowledging the images presented in the social imaginary.

The remembrances occurred because of the affective relations coming from a televisual archive that was exhibited. It is through the social bond, reconstructed by the reminiscences that we visualise the tele-affectivities of the memories. Exemplifying this, the individual that watched Chacrinha's Casino in the ' 80 s saw the attraction, the jury, the chacretes 2 , the narrative context, and the soundtrack that maintained the programme. In that moment, an invisible social bond was created for the free-to-air TV, the collectivity, and referential groups. The television and the programme were also represented in this collectivity and took part in the daily life, and lived moments, of the television viewers. Common and uncommon situations occurred, since it was a lived period and reconstructed a social bond, now by the evoked memories. We can say that the invisible web, which unites people - described by Wolton (1996) through the television - is so powerful that it does not limit itself only to the "equality" of watching a programming, but brings moments marked from the life of each person too.

The archive on the television has this function of bringing back a period through tele-affective memories. It will always have a resignification to the TV audience. This one will not see it only as an archive, but also as a constitutive element in the evocation of their memories. Therefore, feelings will be propelled and relived because of it. Each remembrance is singular, but, consequently, equal to the others, creating a cultural constant: "the past as an accessible imaginary from any mechanism of remembrance" (Silva, 2017, p. 20). Through posts about the remake of a televisual archive, we could

2 Dancing girls who shared the stage with the TV host. 
notice how the social bond is possible throughout remembrances and, particularly, with the actuation of tele-affective memory. All this happens, though, because the re-presented images were recognised in its affective capacity in the act of remembering. Chacrinha is a symbol of the communication of Brazil's social imaginary; he made his mark over several generations and refreshed both memory and the relations with the television in the moment of his re-presentation. This was an analysis that intends to contribute, and promote new debates around the importance of the televisual archive, not only for memory, but also for connection, social bonds, and commitment to social media.

\section{References}

Bardin, L. (2011). Análise de conteúdo. $2^{\text {a }}$ reimp. da 1.ed. São Paulo: Edições 70.

Bressan Júnior, M. A. (2019). Memória Teleafetiva. Florianópolis: Insular.

Cádima, F. (2014). A era digital: primeiros impactos. Lisboa: Media XXI / Formalpress.

Durand, G. (2002). As estruturas antropológicas do imaginário. São Paulo: Martins Fontes.

Eco, U. Tevê: a transparência perdida. In: Eco, U. (1984). Viagem na irrealidade cotidiana. Rio de Janeiro: Nova Fronteira.

Fechine, Y. Elogio à programação: repensando a televisão que não desapareceu. In.: Carlón, M., \& Fechine, Y. (2014). (Orgs.). O fim da televisão. Rio de Janeiro: Confraria do Vento.

Fragoso, S., Recuero, R., \& Amaral, A. (2013) Métodos de pesquisa para internet. Porto Alegre: Sulina.

Halbwachs, M. (2003). A memória coletiva. São Paulo: Centauro.

Lopes, M. I. V., \& Greco, C. Brasil: a "TV transformada" na ficção televisiva brasileira. In: Lopes, M. I. V., \& Gómez, G. O. (2016). (Re)invenção de gêneros e formatos da ficção televisiva: anuário Obitel 2016. Porto Alegre: Sulina.

Brasil: dinâmicas da ficção televisiva na transição multicanal. In: Lopes, M. I. V., \& Gómez, G. O. (2018). Ficção televisiva Ibero-Americana em Plataformas de Vídeo On Demand: anuário Obitel 2018. Porto Alegre: Sulina. 
Maffesoli, M. (2007). O ritmo da vida: variações sobre o imaginário pós-moderno. Rio de Janeiro: Record.

Memória globo. Available at:<http://memoriaglobo.globo. com/perfis/talentos/chacrinha/trajetoria.htm>. Date accessed: 06 jun. 2019.

Moraes, H. J. P. O imaginário no cotidiano: a imagem como potência do laço social. In: Lins, E., \& Moraes, H. J. P., (2019). (orgs). Mídia, cotidiano e imaginário. João Pessoa: Editora da UFPB.

Moraes, H. J. P., Bressan, L. L., \& Jorge, L. C. (2018). Sobre trilhos: a memória revisitada pelo apito do trem - um estudo com as lentes do Imaginário. Desenredo. Revista do Programa de Pós-Graduação em Letras da Universidade de Passo Fundo, v. 14, n. 1, p. 160-176, jan./abr.

Scolari, C. A. ThisistheEnd: As intermináveis discussões sobre o fim da televisão. In.: Carlón, M.; Fechine, Y. (2014). (Orgs.). O fim da televisão. Rio de Janeiro: Confraria do Vento.

Silva, J. M. (2017). Diferença e descobrimento. O que é o imaginário? (A hipótese do excedente de significação). Porto Alegre: Sulina.

Wolton, D. (1996). Elogio do grande público: uma crítica da televisão. São Paulo: Ática. 